\title{
Treatability of Tannery Wastewater by Electrocoagulation Process
}

\author{
Ufuk Durmaz $^{1}$, Fehiman Çiner ${ }^{1}$ \\ ${ }^{1}$ Omer Halisdemir University, Department of Environmental Engineering
}

\begin{tabular}{l}
\hline Article Info \\
\hline Article history: \\
Received June $22^{\text {nd }}, 2017$ \\
Revised June $24^{\text {th }}, 2017$ \\
Accepted June $25^{\text {th }}, 2017$ \\
\hline Keyword: \\
COD \\
Electrocoagulation \\
Leather \\
Tannery wastewater \\
Organized industrial district \\
\hline
\end{tabular}

\begin{abstract}
This study investigated the treatability of tannery industry wastewater by electrocoagulation (EC). The wastewater sample was taken from a leather factory of Mixed Organized Industrial District in Bor-Niğde, Turkey. Treatment of the wastewater was carried out by an electrochemical batch reactor equipped with aluminum electrodes, which were connected parallel to each other. In the EC of the wastewater, the effects of $\mathrm{pH}$, current density and electrolysis time were examined. The optimum operating conditions were determined and applied to the process. The optimum current density for removal of COD and TSS in the tannery wastewater were $18.9 \mathrm{~mA} / \mathrm{cm}^{2}$ and $22.7 \mathrm{~mA} / \mathrm{cm}^{2}$ at $20 \mathrm{~min}$ electrolysis time and $\mathrm{pH} 6$, respectively. The obtained results indicate that $\mathrm{EC}$ reactor is the applicable option to treat tannery industry wastewater in terms of removal efficiency and operating cost.
\end{abstract}

\section{Corresponding Author:}

Fehiman Çiner,

Department of Environmental Engineering,

Ömer Halisdemir University,

51240, Niğde, Turkey.

Email: fciner@ohu.edu.tr

\section{Introduction}

The tannery industry is among the most polluting industries in terms of the volume and the complexity of treatment of its effluents discharge [1]. Major chemicals used for leather manufacturing are lime, sodium and ammonium salts, fatliquors, bacterial and fungicides, tannins, dyes etc. [2]. Wastewaters generated by tannery industry are known to contain large amounts of potentially toxic wastewaters containing both organic and inorganic compounds $[3,4]$. Tanneries effluents are also characterized by high wastewater generation in the range of 30-35 L/ Kg skin/hides process with a variable $\mathrm{pH}$, high concentration of suspended solid, BOD, chromium, COD, and sulfides as well as low biodegradability $[1,5,6]$. The wastewater generated by the tanning, liming, and pickling processes in particular, as well as by the other processes, contains elevated amounts of chromium and dissolved chemical salts. Before discharging this wastewater into a river or other receiving waters, it is necessary to treat the effluent to meet the government's fixed allowable limits [7]. Tannery wastewater treatment represents a serious environmental and technological problem. In fact, after conventional treatment (i.e., chromium precipitation-primary sedimentation-biological oxidation-secondary sedimentation), effluents still do not meet the required limits, at least for some parameters such as COD, salinity, ammonia and surfactants [8]. Conventional physico-chemical treatment methods for tannery wastewater consist of chemical oxidation/precipitation, sedimentation, coagulation/flocculation, adsorption, ion exchange, etc. [9,10]. Conventional biological treatment methods are often inadequate to completely remove pollutants in tannery wastewater [8]. Due to the limitations of the primary and biological wastewater treatment processes, alternative processes have been pursued [2].

In recent years, there has been increasing interest in the use of electrochemical methods in the purification of various industrial wastewaters. Although electrochemical methods are available for more than a century, it now appears to be one of the most effective approaches having the features of low operational cost and high treatment 
efficiency $[11,12,13]$. One of these processes is electrocoagulation (EC) which has achieved much attention due to its attractive advantages as: simple, reliable, and cost-effective operation for the treatment of wastewater. In fact, it involves dissolution of metal from the anode with simultaneous formation of hydroxyl ions, and generation of hydrogen gas at the cathode which can be recovered for use as energy source or a reactant for other industrial applications [14]. There are vital advantages of EC as a low sludge production technology; secondly, the EC flocs are relatively large, contain less bound water, more stable, and amenable to filtration [15]. The fitting choice of EC materials is very essential electrode materials, generally, are aluminum and iron. They are cheap, readily available, and have been proven effective [16]. EC has satisfactory been utilized decades to treat wastewater of olive mill, restaurant, metal plating, domestic, tannery, rose processing, textile industry, etc [13]. The continuous mode of the EC process has however been less investigated, except in a few studies [1].

Electrocoagulation process provides a direct current source between metal electrodes immersed in wastewater. The electrical current causes the dissolution of metal electrodes, and the dissolved metal ions form coagulated species and metal hydroxides, at an appropriate $\mathrm{pH}$. Metal hydroxides, which destabilize and aggregate the suspended particles, precipitate by adsorbing dissolved contaminants. Main processes that occur during electrocoagulation can be given as follows:(i) migration to an oppositely charged electrode and aggregation due to charge neutralization;(ii) formation of cation or hydroxyl ion $(\mathrm{OH}-)$ precipitate with pollutant;(iii) interaction of metallic cation with $\mathrm{OH}$ - to form a hydroxide, which has high adsorption properties thus bonding to the pollutant; (iv) formation of larger lattice-like structured hydroxides which sweep through the water; (v) oxidation of pollutants to less toxic species; (vi) removal by electroflotation or sedimentation and adhesion to bubbles $[14,17,18]$.

In this study, treatability of tannery industry wastewaters by electrocoagulation (EC) was experimentally evaluated. Effects of $\mathrm{pH}$, current density and electrolysis time were analyzed to EC process with aluminum electrode. The optimum operating conditions were determined and applied to the process.

\section{Materials and Methods}

\subsection{Materials}

Tannery industry wastewater sample was taken from a leather factory of Mixed Organized Industrial District in Bor-Niğde, Turkey. The composition of the tannery wastewater are determined using APHA Standard Methods and are presented in Table 1.

Table 1. Characteristics of raw tannery wastewater

\begin{tabular}{lccc}
\hline \multirow{2}{*}{ Parameter } & \multicolumn{3}{c}{ Sample Number } \\
\cline { 2 - 4 } & 1 & 2 & 3 \\
\hline $\mathrm{pH}$ & 9,38 & 7,46 & 7,2 \\
Conductivity $\left(\mathrm{mS} \mathrm{cm}^{-1}\right)$ & 70,6 & 68,9 & 67,7 \\
$\mathrm{COD}\left(\mathrm{mgL}^{-1}\right)$ & 16380 & 19800 & 20440 \\
Total Suspended Solids $\left(\mathrm{mgL}^{-1}\right)$ & 12600 & 1600 & 11500 \\
Chloride $\left(\mathrm{mgL}^{-1}\right)$ & 163 & 14110,3 & - \\
Total Kjeldahl Nitrogen $\left(\mathrm{mgL}^{-1}\right)$ & 1002 & - & - \\
Amonium Nitrogen $\left(\mathrm{mgL}^{-1}\right)$ & - & 1230,6 & - \\
Sulfide $\left(\mathrm{mgL}^{-1}\right)$ & 376 & 106 & - \\
\hline
\end{tabular}

\subsection{Experimental Set-up}

The EC unit consists of an electrochemical reactor, a direct current (DC) power supply and two pairs of aluminum electrodes. The electrochemical reactor was constructed with plexiglas having a dimension of 9x10x10 cm (Fig. 1). The electrodes were placed into $400 \mathrm{~mL}$ wastewater in a $900 \mathrm{~mL}$ plexiglass electrolytic reactor. The electrodes were connected vertically with a gap distance of $10 \mathrm{~mm}$. There were four electrodes connected in a monopolar mode in the electrochemical reactor, each one with dimensions of $5.5 \mathrm{~cm} \times 3.5 \mathrm{~cm} \times 0.4$ $\mathrm{cm}$. The electrodes were placed in the reactor vertical position, and connected to a DC power source. 


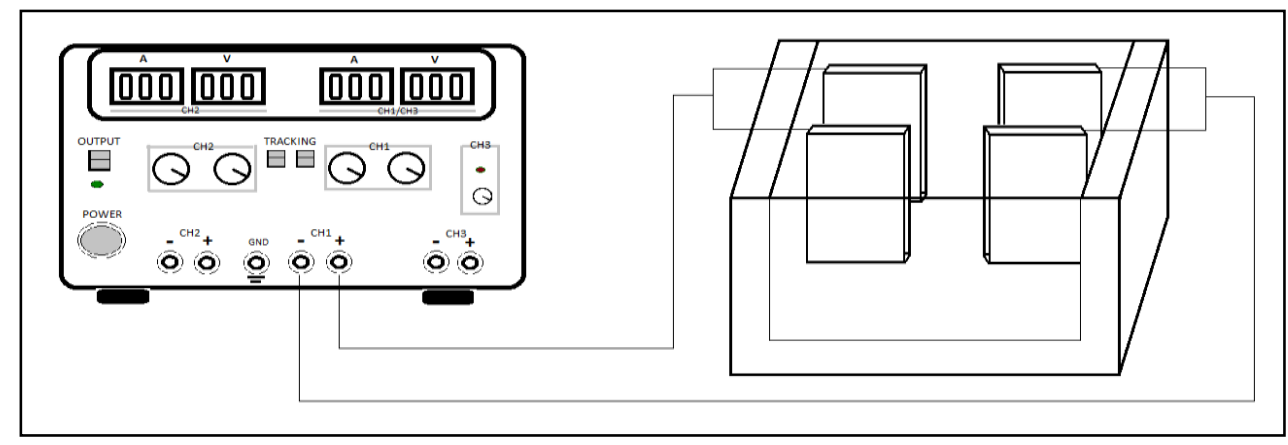

Figure 1. Schematic diagram of EC reactor.

The stirrer was used in the electrochemical cell to maintain an unchanged composition and avoid the association of the flocs in the solution. The DC source was used to power supply the system with $0-15 \mathrm{~V}$ and $0-3 \mathrm{~A}$. A GW INSTEK multimeter, model SPD-3606, was used for measurement the current and the potential between the two electrodes. The operating parameters and conditions are summarized in Table 2. At the beginning of a run the wastewater was fed into the reactor and the $\mathrm{pH}$ was adjusted to a desired value using $1 \mathrm{~N} \mathrm{HCl}$ or $\mathrm{NaOH}$ solutions. Electrochemical batch reactor equipped with aluminum electrodes, which were connected parallel to each other. During the whole experiment, conductivity and $\mathrm{pH}$ of solution was recorded. Electrodes were washed with dilute $\mathrm{HCl}$ between the experiments.

Table 2. Conditions and operating parameters

\begin{tabular}{ll}
\hline Operating Parameter & Value \\
\hline Current density $\left(\mathrm{mA} / \mathrm{cm}^{2}\right)$ & $11-38$ \\
Electrode number (pair) & 2 \\
Electrode gap $(\mathrm{cm})$ & 1 \\
Wastewater volume $(\mathrm{mL})$ & 400 \\
$\begin{array}{l}\text { Electrocoagulation time } \\
\text { (min) }\end{array}$ & $20,30,45,60,90$ \\
Initial pH & $2-8$ \\
\hline
\end{tabular}

\subsection{Analytical Procedure}

The wastewater analyses such as $\mathrm{pH}$, conductivity, COD and total suspended solids (TSS)were carried out in accordance with the Standard Methods for Examination of Water and Wastewater. The supernatant were filtered with cellulose acetate filter paper before COD analyses.

The removal efficiency (E) was calculated using the following equation:

$$
E=\frac{Y_{0}-Y}{Y_{0}} \times 100
$$

where $\mathrm{E}$ is the removal efficiency $(\%), \mathrm{Y}_{\mathrm{o}}$ and $\mathrm{Y}$ were initial and final values of COD and SS, respectively.

\section{Results and Discussion}

In order to improve the process performance, the effects of current density, $\mathrm{pH}$ solution and electrolysis time have been investigated. The removal of COD and TSS with energy consumption from tannery industry wastewater was investigated by EC method using aluminum electrode.

\subsection{Effect of Initial pH}

It has been established that $\mathrm{pH}$ is an important parameter influencing the performance of the EC process. Charge on hydrolysis products and precipitation of metal hydroxides are both controlled by $\mathrm{pH}$ variations [19].To examine its effect on the treatment efficiency, the $\mathrm{pH}$ was varied in the range of $2-8$ and the results are shown in Fig. 2. 


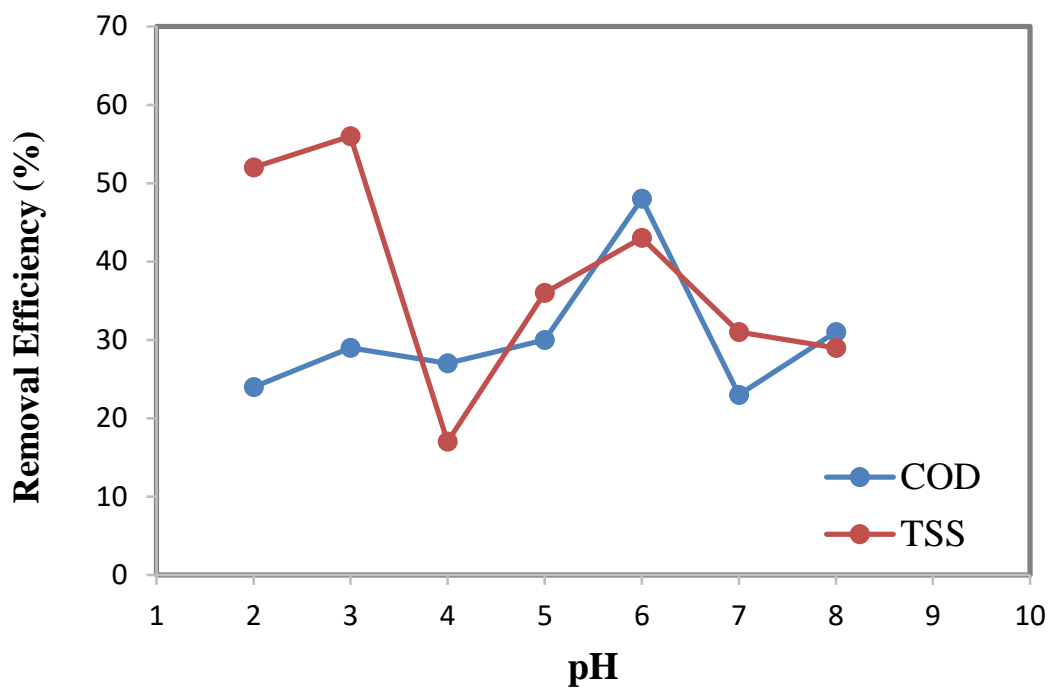

Figure 2. Effect of initial $\mathrm{pH}$ on the removal efficiency of tannery wastewater

It was found that the percentage of COD and TSS removal are higher at a near neutral $\mathrm{pH}$. As the $\mathrm{pH}$ increased, there was decrease in the percentage of COD and TSS removal; efficiency was at its maximum at a pH 6.0. From the figure, we observed that the optimum conditions maximum COD and TSS removal attainables are respectively $48 \%$ and $43 \%$ with aluminum on $\mathrm{pH} 6.0$, at the end of $20 \mathrm{~min}$ of the electrolysis time.

\subsection{Effect of Electrolysis Time}

Electrolysis time is one of the important parameter which affects the EC process significantly [19]. In order to investigate the effect of electrolysis time on treatment efficiency, the experiments were carried out by varying the electrolysis time from 20 to $90 \mathrm{~min}$ at $\mathrm{pH} 6.0$ and the results are shown in Fig. 3.

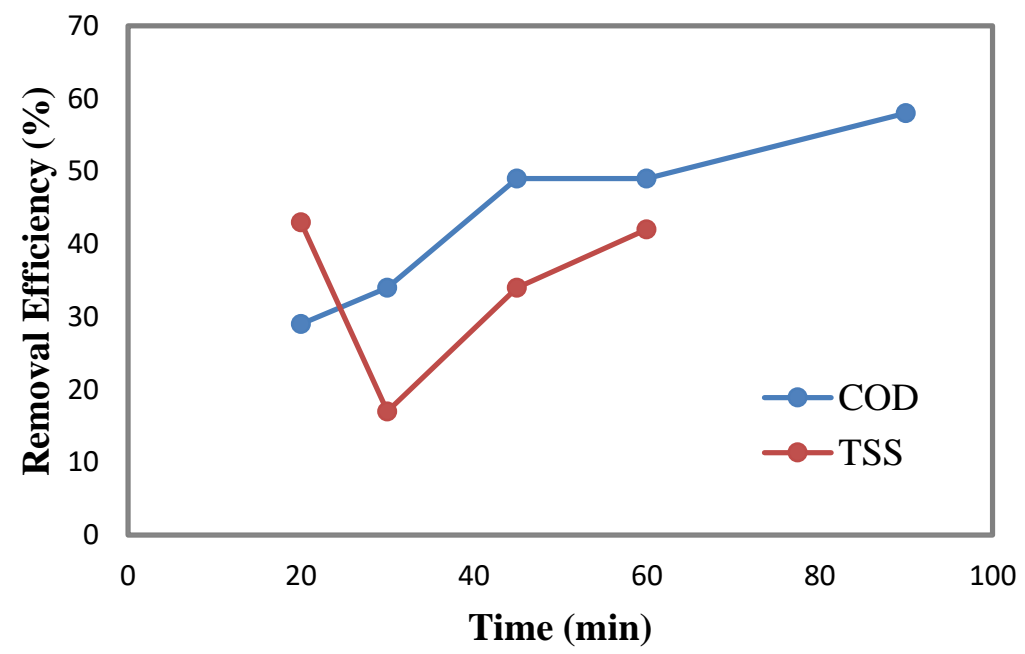

Figure 3. Effect of electrolysis time on the removal efficiency of tannery wastewater

From the figure, it is found that the percentage of COD and TSS removals were increased with increasing electrolysis time up to $60 \mathrm{~min}$. Maximum COD and TSS removal achieved are $49 \%$ and $42 \%$, respectively with aluminum at $60 \mathrm{~min}$ electrolysis time.

\subsection{Effect of Current Density}

Current density is one of the most important parameters which shows the significant effect on the treatment efficiency of EC process [19]. In order to study the effect ofcurrent density on the maximum removal efficiency 
of COD and TSS experiments werecarried out in various current densities $11-38 \mathrm{~mA} / \mathrm{cm}^{2}$ at $\mathrm{pH} 6.0$ and electrolysis time 20 min, and results are depicted in Fig.4.

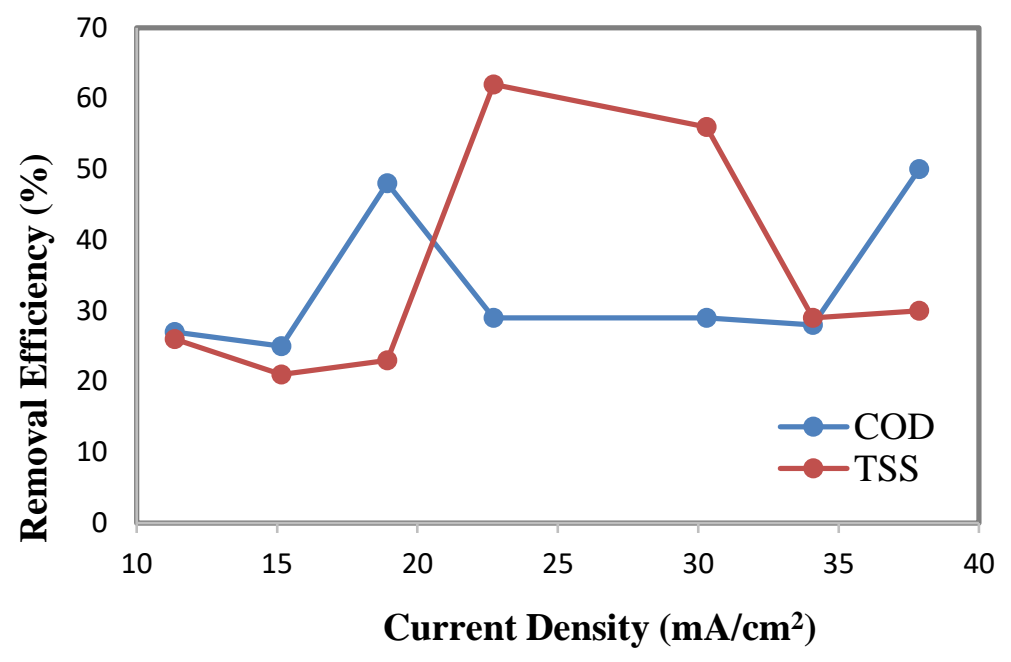

Figure 4. Effect of current density on the removal efficiency of tannery wastewater

From the results, it was found that the removal efficiency of COD and TSS was increased with increasing current density up to $38 \mathrm{~mA} / \mathrm{cm}^{2}$ and $22.7 \mathrm{~mA} / \mathrm{cm}^{2}$, respectively.

\subsection{Determination of Energy Consumption}

Electrical energy consumption was calculated the following equation:

$$
\mathrm{E}=\frac{\text { U.I.t }}{\mathrm{V}}
$$

where $\mathrm{E}$ is the energy consumption $\left(\mathrm{kWh} / \mathrm{m}^{3}\right), \mathrm{U}$ is the applied voltage $(\mathrm{V}), \mathrm{I}$ is the current density $(\mathrm{A}), \mathrm{t}$ is the electrocoagulation time $(\mathrm{h}), \mathrm{V}$ is the volume of the treated wastewater $(\mathrm{L})$.

However, it is noticed that increasing current density increases the energy consumption with time throughout the experiment due to the consumption of higher voltage during the EC process(Fig. 5).

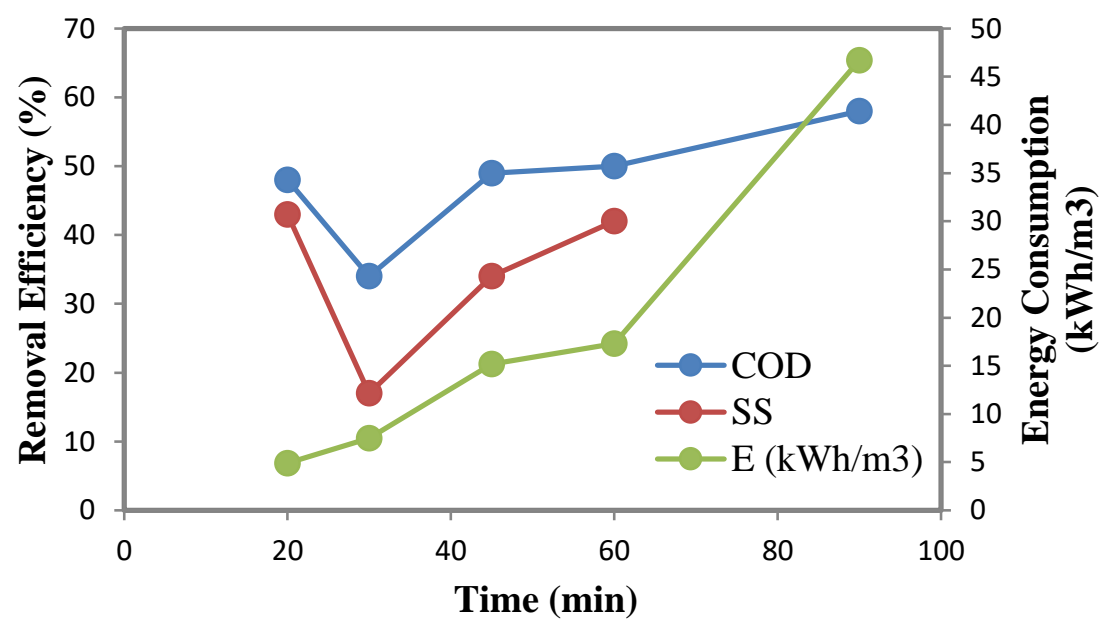

Figure 5. Effect of time on pollutants removal efficiency and energy consumption of electrocoagulation

\section{Conclusions}

In this study investigated the possibilities of electrocoagulation reactorto reduce the COD and TSS from tannery industry wastewater using $\mathrm{Al}$ electrodes. Effects of $\mathrm{pH}$, electrolysis time and current density were analyzed to optimize the electrocoagulation process. Optimum operating conditions such as $\mathrm{pH}$ of 6.0,electrolysis time of $60 \mathrm{~min}$, current density $22.7 \mathrm{~mA} / \mathrm{cm}^{2}$ show $49 \%$ of COD and $42 \%$ of TSS removal, respectively. The electrical energy consumption of the present treatment process in optimum condition was found to be $17.25 \mathrm{KWh} / \mathrm{m}^{3}$. 
The application of EC process to tannery wastewater as an alternative pretreatment was found to be very effective. The results show that approximately $50 \%$ reductions in all parameters tested.

\section{Acknowledgments}

This research has been supported by Ömer Halisdemir University Scientific Research Projects Coordination Unit. Project Number: FEB 2015/30 YÜLTEP, 2015. Some part of this study was presented in 3rd International Conference on Engineering and Natural Science (Budapest, Hungary) and its abstract was published in Book of Abstract of this conference.

\section{References}

[1]. A. Deghles and U. Kurt, "Treatment of tannery wastewater by a hybrid electrocoagulation/ electrodialysis process", Chemical Engineering and Processing vol. 104, pp.43-50, 2016.

[2]. İ.A. Şengil, S. Kulaç and M. Özacar, "Treatment of tannery liming drum wastewater by electrocoagulation",Journal of Hazardous Materials, vol. 167, pp. 940-946, 2009.

[3]. L. Szpyrkowicz, G.H. Kelsall, S.N. Kaul and M.D. Faveri, "Performance of electrochemical reactor for treatment of tannery wastewaters", Chem. Eng. Sci., vol. 56, pp.1579-1586,2001.

[4]. A. Cassano, R. Molinari, M. Romano and E. Drioli, "Treatment of aqueous effluents of the leather industry by membrane processes: A review", J. Membr. Sci.,vol. 181, pp. 111-126, 2001.

[5]. F.M. Menezes, R. Amal and D. Luketina, "Removal of particles using coagulation and flocculation in a dynamic separator", Powder Technol., vol. 88, pp.27-31, 1996.

[6]. Z. Song, C.J. Williams and R.G.J. Edyvean, "Treatment of tannery wastewater by chemical coagulation", Desalination, vol. 164, pp. 249-259, 2004.

[7]. K. M. Zeinu and O. Sahu, "Adsorption of Chromium From Tannery Wastewater by Surface Response Method", Environmental Quality Management, DOI 10.1002 tqem, 2015.

[8]. U. Kurt, Ö. Apaydın and M.T. Gönüllü, "Reduction of COD in wastewater from an organized tanneryindustrial region by Electro-Fenton process",Journal of Hazardous Materials, vol. 143, pp. 33-40, 2007.

[9]. R. Ramesh Babu, N.S. Bhadrinarayana, K.M. Meera and S. Begum, "Treatment of tannery waste water by electro-coagulation", J Univ Chem Technol Metall, vol. 42(2), pp. 201-206, 2007.

[10].Keerthi, V. Vinduja and N. Balasubramanian, "Electrocoagulation-integrated hybrid membrane processesfor the treatment of tannery wastewater", Environ Sci Pollut Res, vol. 20, pp. 7441-7449, 2013.

[11].M. Kobya, E. Demirbas, M. Bayramoglu and M.T. Sensoy, "Optimization of electrocoagulation process for the treatment of metal cutting wastewaters with response surface methodology", Water Air Soil Pollut, vol. 215, pp.399-410, 2011.

[12].A. Akyol, O.T. Can, E. Demirbas and M. Kobya, "A comparative study of electrocoagulation and electroFenton for treatment of wastewater from liquid organic fertilizer plant”, Sep. Purif. Technol., vol. 112, pp. 11-19, 2013.

[13].G. Varank, S. Yazici Guvenc, G. Gurbuz and G. Onkal Engin, "Statistical optimization of process parametersfor tannery wastewater treatment byelectrocoagulation and electro-Fenton techniques", Desalination and Water Treatment, doi: 10.1080/19443994.2016.1157042, pp. 1-14, 2016.

[14].C. Phalakornkule, P. Sukkasem and C. Mutchimsattha, "Hydrogen recovery from the electrocoagulation treatment of dye-containing wastewater", Int. J. Hydrogen Energy, vol. 35, pp. 10934-10943, 2010.

[15].P. Holt, G. Barton and C. Mitchell, "Electrocoagulation as wastewater treatment", The Third Annual Australian Environmental Engineering Research Event, 23-26 November, 1999, pp. 23-26.

[16].B.G. Chen, X. Chen and P.L. Yue, "Electrocoagulation and electroflotation of restaurant wastewater", $J$. Environ. Eng.,vol. 126 (9),Paper No. 21505, 2000.

[17].R. Katal and H. Pahlavanzadeh, "Influence of different combinations of aluminum and iron electrode on electrocoagulation efficiency: Application to the treatment of paper mill wastewater", Desalination, vol. 265, pp.199-205, 2011.

[18].G. Chen, "Electrochemical technologies in wastewater treatment", Sep. Purif. Technol., vol. 38, pp. 1141, 2004.

[19].K. Thirugnanasambandham and V. Sivakumar, "Removal of ecotoxicological matters from tannery wastewater using electrocoagulation reactor: modelling and optimization", Desalination and Water Treatment, vol. 57, pp. 3871-3880, 2016. 